\title{
The Effects of Jigsaw Learning on Students' Knowledge Retention in Vietnamese Higher Education
}

\author{
Tran Van Dat ${ }^{1}$ \\ ${ }^{1}$ Head of Academic Affairs Office, An Giang University, Vietnam \\ Correspondence: Tran Van Dat, Head of Academic Affairs Office, An Giang University, Vietnam
}

Received: April 1, 2016

Accepted: April 12, 2016

Online Published: April 15, 2016

doi:10.5430/ijhe.v5n2p236

URL: http://dx.doi.org/10.5430/ijhe.v5n2p236

\begin{abstract}
As part of an experimental study on the effects of jigsaw learning on Vietnamese tertiary students' longer term achievement in a course of Management of Education and Administration, knowledge retention after one month was investigated. As reported in our previous papers, students in the cooperative jigsaw group $(\mathrm{N}=40)$, perceived their instruction as more cooperative and more student-centered, and less teacher-centered than did those in the lecture group $(\mathrm{N}=40)$. They also obtained significantly higher scores on a post experiment achievement test than did the others. Results indicate that in general students in the cooperative jigsaw group appreciated most working with others and getting help, discussing and sharing information and teaching others, and enjoyed the jigsaw context. This paper furthers that analysis by investigating students' knowledge retention. The findings show that a month after the experiment, students in the jigsaw group had greater long-term achievement than those did in the lecture group. However, students in both groups had a similar percentage of knowledge retention on the delay test of achievement. They retained nearly all of what they had learned (approximately 99 percent of knowledge) a month after the six weeks of the instruction.
\end{abstract}

Keywords: Cooperative learning, Jigsaw learning, Knowledge retention, Achievement, Attitudes

\section{Introduction}

One of the major objectives of teachers is to effectively use instructional strategies to improve students' cognitive and affective outcomes. In recent years, research involving cooperative learning, one kind of student-centered approach, has emerged as an internationally important area of social science research (Slavin, 2011). A series of research studies has found a substantial relationship between better cognitive and affective outcomes, and cooperative learning approaches (Johnson \& Johnson, 2005). In the setting of Vietnamese Higher Education Institutions (VHEI) lecture-based teaching, one kind of traditional approach, remains the most prevalent instructional approach (MOET, 2009). The lecture-based teaching used by teachers in VHEI has been argued to have created many problems. Firstly, many students display little initiative when learning, so that they are more reliant on the teacher as a source of knowledge rather seeking information from other sources and learning from other students (Harman \& Nguyen, 2010). Secondly, the majority of students tend to learn the subject matter by memorization rather than by understanding (Pham, 2010). Thirdly, many students lack the ability to enhance their academic achievement and learning skills (Harman \& Nguyen, 2010; Director, Doughty, Gray, Hopcroft, \& Silvera, 2006). Finally, lectures tend to focus on the lower-order level of thinking [surface learning] rather than the higher-order level of thinking [deep learning] (Sherian, 2010). Surface learning mainly depends on the simple recall of information rather the complex assimilation of information and evaluation. It has been argued that the current teaching and learning situation in VHEI would improve if the time for lectures was reduced in order to increase the time for student discussion of the learning tasks, and reciprocal interaction among students in the classroom (Johnson \& Johnson, 2009; Tran \& Lewis, 2011a). In this paper, the effect of cooperative learning on student retention of learning will be considered.

\section{Literature Review}

\subsection{Cooperative Learning}

Although researchers have not used the same official definition of cooperative learning, all of them refer to cooperative learning as a "set of methods in which students work together in small groups and help one another to achieve learning objectives" (Johnson \& Johnson, 2009, p.69). In other words, cooperative learning is the pedagogy 
within which students are active constructors of knowledge in the learning process instead of passive receivers of any given knowledge (Liang, 2002). Jigsaw grouping, one kind of cooperative learning method, developed by Aronson, Blaney, Stephan, Sikes and Snapp (1978) helps students break learning materials into manageable learning pieces (small picture), and then integrate all the learning pieces into a meaningful whole (big picture). Jigsaw learning is based on the perspective that each student will first become "an expert" in a small part of the whole learning material, and then teach other students about this part of the material. As reported in our previous reports (Tran \& Lewis, 2012a\&b), the jigsaw learning method was employed in the treatment group to allow a comparison of the effects of the jigsaw learning and the lecture-based teaching on students' academic achievement, and their attitudes toward this kind of learning. This paper investigates the effects of cooperative learning on students' knowledge retention. Conducting cooperative learning does not mean that we simply let students sit next to each other at the same desk and ask them to do their own tasks (Gillies, 2003). Johnson \& Johnson (1998) claim that "placing people in the same room, seating them together, telling them that they are a cooperative group, and advising them to 'cooperate', does not make them a cooperative group" (p.15). A cooperative learning environment will exist if groups are structured in such a way that group members co-ordinate activities to facilitate one another's learning (Ballantine \& Larres, 2007). In order to engage students in learning, five elements must be present in the cooperative classroom (Johnson \& Johnson, 2008). These are positive interdependence, face-to-face interaction, individual accountability, interpersonal \& social skills, and group processing. If these basic elements are present in cooperative learning groups, students achieve better and demonstrate superior learning skills (Johnson \& Johnson, 2008). Once these five elements are structured in cooperative settings, the roles of the teacher and students will be changed remarkably. The teacher becomes not the 'sage on the stage', but 'the guide on the side' (Johnson, Johnson, \& Holubec, 1994).

\subsection{Research Findings on Cooperative Learning on Achievement and Knowledge Retention}

The effectiveness of cooperative learning has received much attention because of the many positive research findings on this kind of learning which are reported in the literature. However, almost all studies that have investigated the benefits of cooperative learning were conducted in Western contexts. Further, most studies have been carried out in primary and secondary levels, while very few studies have been conducted in high schools and at college level (Johnson \& Johnson, 2005). In Asian contexts [including Vietnam], there are not many systematic research studies on cooperative learning, although this approach has been "a key pedagogic component of many education reform strategies" (Nguyen, Elliott, Terlouw, \& Pilot, 2009, p.114). To investigate how cooperative learning affects Vietnamese tertiary students' learning this study firstly reviews some recent studies in both Western and Asian contexts.

\subsubsection{Cooperative Learning Research in the Western Context}

To investigate the effects of cooperative learning on student learning ten relevant studies conducted in Western contexts will now be reviewed. In these studies the pretest and post-test with the control group design was used to investigate dependent variables (e.g. achievement, long-term achievement), and the duration of these studies was at least 4 weeks, with the exception of the study by Tanel \& Erol (2008) which used only the post-test with the control group. Results reported show that of the 10 studies, 9 report significantly higher achievement in cooperative learning groups than in control groups. Only one study found no significant differences. Of these studies, only three measured long-term achievement, with 2 reporting significantly greater long-term achievement in cooperative learning groups, and one study reporting no differences. For example, one study of the Jigsaw II and Group Investigation (GI) effect among 98 elementary school students in social studies, lasting 12 weeks in America (Lampe, Rooze, \& Tallent-Runnels, 1996), indicated that students in the experimental group $(n=45)$ had higher academic achievement $(\mathrm{p}<.001)$ than those in the control group $(\mathrm{n}=53)$ (effect size $=.84)$. Whicker, Nunnery, \& Bol (1997) compared the effects of Student Teams Achievement Divisions (STAD) and traditional teaching methods on academic performance of $11^{\text {th }}$ - and $12^{\text {th }}$-grade students in a mathematics course in America. The results from the post-tests showed that students in the cooperative learning group $(n=15)$ achieved significantly $(\mathrm{p}<.05)$ higher post-test scores than did students in the comparison group $(\mathrm{n}=16)$ (effect size $=.87$ ). Similarly, a two-group experiment reported by Yamarik (2007), investigated the jigsaw effects on the achievement of 116 American tertiary students in a 2-semester period. Results obtained from multivariate regression analysis reveal that the jigsaw group $(n=57)$ significantly outperformed $(\mathrm{p}<.05)$ the comparison group $(\mathrm{n}=59)$ on the post-test scores (effect size $=.01)$. In a 5 -week experimental study on science achievement of 68 eighth-grade Turkish students (Kose, Sahin, Ergun, \& Gezer, 2010), the results of t-tests indicated that students in the treatment group $(n=33)$ significantly outscored $(\mathrm{p}<.05)$ students in the control group $(\mathrm{n}=35)$ on the post-achievement test (effect size $=1.26)$. In addition, the other two experimental studies (Kilic, 2008; \& Doymus, Karacon, \& Simsek, 2010) utilized the pre-test and post-test with control group 
design to investigate the effects of jigsaw learning on student achievement. The former was conducted with the participation of 80 Turkish tertiary students (40 students in the jigsaw group and 40 students in the control group) in a Principles and Methods of Teaching course over a 7-week period. The latter was carried out with 73 Turkish tertiary students in a Chemistry course over a one-year period. At the end of the experiment, the former shows that the jigsaw group $(n=40)$ had higher post-test achievement scores $(\mathrm{p}<.01)$ than the control group $(\mathrm{n}=40)$ (effect size $=1.13)$. The latter reports that the jigsaw group $(\mathrm{n}=36)$ significantly outperformed $(\mathrm{p}<.001)$ the traditional learning group $(\mathrm{n}=37)$ (effect size $=2.62)$. Similarly, Beck \& Chizhik (2008) compared the effects of cooperative learning and other teaching methods on 71 tertiary student performances in a computer science course in America over a period of one year, and found that the cooperative learning group $(\mathrm{n}=34)$ achieved significantly higher $(\mathrm{p}$ $<.01)$ than the conventional lecture teaching group $(\mathrm{n}=37)$.

As indicated above, students perform better with cooperative learning than they do with alternative forms of instruction, as reported in the above studies, which further confirms the results of several previous reviews of cooperative learning research (Slavin, 1983\&1990; Johnson \& Johnson, 1981\&1989). These studies were conducted at various levels of education, in different subject areas, and in different countries. For example, in an extensive review of over 375 studies yielding 1,691 findings conducted by Johnson \& Johnson (1989), reported that

When all of the studies were included in the analysis, the average student cooperating performed at about two-thirds a standard deviation about the average student learning within a competitive (effect size $=0.67)$ situation or individualistic (effect size $=0.64$ ) situation. When only high-quality studies were included in the analysis, the effect sizes were 0.88 and 0.61 respectively (p.38).

In promoting greater achievement, some additional studies reported that cooperative learning also fosters greater retention of learning, as indicated by students' results on delayed achievement tests (Sousa, 2006; Moore, 2008). For example, Sousa (2006) reports the average percentage of learning material retention after 24 hours when students were taught by different teaching methods. He indicates that there is retention of $50 \%$ of material learned in the discussion group, $75 \%$ as a result of requests for students to study through practice, and $90 \%$ when students teach others. In addition, Moore (2008) reports studies showing that a blend of 'telling' and 'showing' techniques results in greater retention (65\%) after three days. It is therefore argued that the best way to learn something effectively is to prepare to teach it. In other words, whoever explains, learns (Sousa, 2006). Teaching others and elaborating ideas are the main features of cooperative learning (Kagan \& Kagan, 2009; Slavin, 2011). The nature of cooperative learning is learning by doing (Liang, 2002) and elaborating (McKeachie, 1999). In cooperative learning situations, the concepts being taught are often elaborated (McKeachie, 1999; O’Donnell, 1996\&2000). The consistent elaboration of learning concepts provides students who either receive the explanation or those who give the explanation with a deep understanding and a more complete retention of the concepts being learnt for a longer period of time (Chianson, Kurumeh \& Obida, 2010). Consequently, as has been shown in the above review, in cooperative situations, students retain more knowledge when they offer more explanation and elaboration to others (Zakaria, Chin, \& Daud, 2010; Webb, 2008; Johnson \& Johnson, 1989).

Some studies have reported the effects of different forms of pedagogy on retention of learning. For example, an impressive study lasting 4 weeks was conducted by Tanel \& Erol (2008) in which the effectiveness of the jigsaw learning method and conventional teaching method were compared on achievement and retention in a Physics course in a University in Turkey. An experimental group $(n=50)$ received the jigsaw technique and a control group $(n=50)$ received traditional teaching. At the end of the treatment, a post-test was administered, while the delay-test was administered 4 weeks after the treatment. The post-test and delay test mean scores of the jigsaw group $(\mathrm{M}=12.74$, $\mathrm{SD}=3.98 ; \mathrm{M}=12.60, \mathrm{SD}=3.74$, respectively) were significantly higher $(\mathrm{p}<.05)$ than those of the control group $(\mathrm{M}=8.36, \mathrm{SD}=3.04 ; \mathrm{M}=6.70, \mathrm{SD}=2.26$, respectively $)$. Results from the t-tests indicated that there were significant differences $(\mathrm{p}<.001)$ on the post-test scores (effect size $=1.24)$ and the delayed-test achievement scores (effect size $=1.96$ ). The experimental students had greater achievement and long-term achievement than those in the control group. An inspection of post-test scores and delay test scores for each group shows that four weeks after the experiment the students in the experimental group retained nearly $98 \%$ of their knowledge on the delay test whereas those in the control group retained nearly 80 percent. Sahin (2010) also used a pre-test and post-test design to investigate the effects of Jigsaw III on achievement, and retention, of 71 Turkish sixth-grade students in a Turkish course over a 6-week period. The post-test was administered at the end of the treatment, while the delay test was administered 6 weeks after the treatment. The post-test and delay test mean scores of the students in the jigsaw group were $23.50(\mathrm{SD}=1.87)$ and $18.51(\mathrm{SD}=1.63)$, respectively, while those of the students in the control group were $21.74(\mathrm{SD}=2.19)$ and $17.23(\mathrm{SD}=2.07)$, respectively. Results from the t-tests indicated that students in the jigsaw group $(n=36)$ outscored on the achievement test $(\mathrm{p}<.001)$ those in the traditional lecture-based learning group $(\mathrm{n}=$ 
35) (effect size $=.86)$. The jigsaw group also had greater long-term achievement on the delay test $(\mathrm{p}<.05)$ than those in the control group (effect size $=.69$ ). However, an inspection of post-test and delay test scores for each group shows that six weeks after the experiment students in both groups had a similar percentage of knowledge retention (approximately 79 percent of their post test achievement). Souvignier \& Kronenberger (2007) reported the effectiveness of jigsaw learning on mathematics and science achievement, and knowledge retention of 208 third-grade students in Germany. The study lasted 12 weeks, and three conditions of instructions were compared: jigsaw $(n=70)$, jigsaw with additional questioning training $(n=67)$ and teacher-guided instruction $(n=71)$. The pre-tests were administered to control for differences in academic ability before the treatment, the post-achievement tests were administered at the end of the treatment, and the delayed tests were administered 3 months after the treatment. Results obtained from one-way ANOVA analyses showed no significant differences between the three conditions on learning preconditions. At the end of the treatment, the post-test and delay test mean scores of students in the teacher-guided instruction condition $(\mathrm{M}=16.09, \mathrm{SD}=14.51 ; \mathrm{M}=9.31, \mathrm{SD}=2.76$, respectively) were higher than those of students in the jigsaw condition $(\mathrm{M}=13.97, \mathrm{SD}=6.52 ; \mathrm{M}=7.88, \mathrm{SD}=2.81$, respectively) or those of students in the jigsaw with questioning condition $(\mathrm{M}=14.02, \mathrm{SD}=4.60 ; \mathrm{M}=8.03, \mathrm{SD}=2.68$, respectively $)$. The results of t-tests indicated no significant differences $(\mathrm{p}>.01)$ between the jigsaw conditions and the teacher-guided instruction conditions on students' achievement and their long-term achievement in the maths units. Inspection of both tests for each condition shows that students in three conditions had a similar percentage of knowledge retention on the delay test, recording nearly 57 percent retention. Similarly, Wyk (2010) examines the effects of GTG on the achievement and knowledge retention of 110 economics education students in South Africa, and reports no significant differences $(\mathrm{p}>.05)$ for achievement or retention between the teaching methods used over 12 weeks of instruction. Students in the GTG group $(n=57)$ and the lecture-based teaching group $(n=53)$. The post-test and delay test mean scores of students in the GTG $(n=57)(M=20.67$ and $M=20.89$, respectively) were higher than those of students in the conventional teaching group $(n=53)(M=20.52$ and $M=20.41$, respectively). An inspection of scores for each group shows that both group had similar retention (approximately 99\%) on the delay test of achievement. The findings of the above studies validate the results of a two-week period conducted by Abu \& Flowers (1997) in which the effectiveness of the STAD method and lecture-based teaching method were compared on two dependent variables (achievement, and retention) in a home economic course in a University in America. A cooperative learning group $(n=91)$ received the STAD technique and a control group $(n=106)$ received conventional teaching. At the end of the treatment, a post-test was administered, and the delay-test was administered 3 weeks after the treatment. Results show that the students in the STAD group had higher post-test and delay test scores than those in the conventional teaching group. However, the multivariate analysis shows no significant differences $(p>.05)$ for post-test achievement and knowledge retention between the treatment groups. The data shows that the adjusted post-test and delay test mean scores for the cooperative learning group were 19.61 and 19.52, respectively while those for the conventional teaching group were 18.49 and 18.41 , respectively. An inspection of scores for each group indicates that the percentage of knowledge retention in both groups is similar. Students in both group retained approximately $99 \%$ of knowledge two weeks after the experiment.

In summary, the review of the above studies, some additional studies on cooperative learning in some Western countries, one study in South Africa, and some reviews and meta-analytic studies examined above, supports the effectiveness of cooperative learning on students' academic achievement and long-term achievement, as well as knowledge retention.

\subsubsection{Cooperative Learning Research in the Asian Context}

This concluding section of the literature review focuses on the effects of cooperative learning research in Asian contexts (e.g. China, Hong Kong, Taiwan, Singapore, Malaysia, and Vietnam). Although there is research which indicates that students from collectivistic Asian cultures value working in groups, and perform well in groups (Hofstede \& Hofstede, 2005; Park, 2002; Volet \& Renshaw, 1996), it is necessary to systematically examine the extent to which cooperative learning works and affects students' learning, where Confucianism has a powerful influence on norms, values, and behavior of learners (Nguyen, Terlouw, Pilot, \& Elliott, 2009). Consequently, ten relevant experimental studies of cooperative learning conducted in Asian contexts will be reviewed. Six studies were conducted at the levels of primary and secondary school, and four at University level. Of the ten studies, four reported significantly higher achievement in the treatment groups than in the control groups, four showed no significant difference between the two groups, and two revealed significant effects favoring the control group.

In a one-semester study of the effects of STAD and Learning Together on 70 Taiwanese secondary school students' oral communicative competence in English and their attitudes, Liang (2002) reported that students in the experimental group $(\mathrm{n}=35)$ had significantly higher performance scores $(\mathrm{p}<.05)$ than those in the control group $(\mathrm{n}=$ 
35) $(\mathrm{M}=76.80, \mathrm{SD}=5.70 ; \mathrm{M}=69.53, \mathrm{SD}=8.33$, respectively). Hwang, Lui, \& Tong's findings (2005) supported this result when they utilized a $2 \times 2$ between-subjects experimental design to examine cooperative learning effects on the learning outcomes of 172 accounting students in a major Hong Kong university. Results show that the students in the cooperative learning group performed better in answering indirect application-type questions than those in the traditional lecture group. The post-test scores of the cooperative learning group $(\mathrm{M}=6.60)$ were significantly higher than that of the control group $(M=5.70)$. Similarly, the effects of STAD and traditional lecture teaching on the academic performance of tertiary students in an English course in Taiwan were compared by Cheng (2006). Results show that students in the cooperative learning group $(\mathrm{n}=49)$ achieved significantly higher $(\mathrm{p}<.05)$ on post-test scores than students in the traditional lecture teaching group $(\mathrm{n}=48)(\mathrm{M}=74.23, \mathrm{SD}=12.28 ; \mathrm{M}=68.46$, $\mathrm{SD}=10.44$ ). Finally, in a two-group experimental design, Luu (2010) investigated the Learning Together effects on the reading competence of 77 Vietnamese tertiary students over a 7-week-period. Results show that the small cooperative learning group $(n=40)$ outperformed $(\mathrm{p}<.05)$ the comparison group $(\mathrm{n}=37)$ on the post-test scores in reading competence $(\mathrm{M}=6.12 ; \mathrm{M}=6.02$, respectively).

As reported earlier, there are four studies for which the results on students' achievement in the treatment and control groups was not significantly different ( $p>.05)$. In a two-semester study on linguistic competence achievement and attitudes of 21 secondary school students in Hong Kong, Eva (2003) reported that there were no significant differences $(\mathrm{p}>.05)$ on linguistics competence between the treatment group and the control group. The other two experimental studies (Chung, 1999; \& Sachs, Candlin, Rose, \& Shum, 2003) also show there were no significant differences ( $p>.05$ ) in achievement between the experimental students and the control students. The former was conducted with the participation of 23 primary school students in a mathematics course in Hong Kong in a one-semester period. Results show that there were no significant differences $(p>.05)$ on mathematics achievement between the treatment group $(n=13)$, where Team Accelerated Instruction (TAI) was employed, and the control group $(\mathrm{n}=10)$, where whole-class traditional teaching was used. The latter was carried out with 120 primary school students in an English course in a one-year period. The findings reveal no significant differences $(p>.05)$ in oral performance scores between students in small cooperative learning groups and in traditional lecture teaching groups. Similarly, Zain, Subramaniam, Rashid, Shani (2009) investigated the STAD effects on achievement of 61 Malaysian tertiary students in an Economics course of a one-semester duration, and reported that there was no significant difference $(\mathrm{p}>.05)$ on post-test achievement scores between the STAD group $(\mathrm{n}=31)$ and the traditional teaching group $(\mathrm{n}=30)$ The review also shows that in two studies, students in the traditional lecture-based groups significantly outperformed ( $\mathrm{p}<.05)$ those in the cooperative learning groups. Messier (2003) compared the effects of cooperative learning and the traditional lecture teaching on 95 secondary school student on grammar performances in an English course in China over a period of 4 weeks. There were four experimental groups, and four control groups. Results show that achievement scores in the conventional lecture teaching groups were significantly higher $(\mathrm{p}<.05)$ than in the small cooperative learning groups. Another study (Tan, Sharan, \& Lee, 2007) lasting six weeks, conducted in Singapore, had similar findings. The study compared the impact of the GI method and a conventional teaching method on secondary school students' achievement in Geography. The study reported that students in two traditional lecture-based teaching groups significantly outperformed those in two treatment groups.

This review confirms, to some extent, the findings of Thanh-Pham, Gilles, \& Renshaw (2008), who conducted a review of 14 studies on cooperative learning in the Asian context. They identified 14 high-quality studies that compared the impact of cooperative learning and traditional lecture-based teaching on student achievement, and reported that 7 studies showed significantly higher achievement in the treatment groups than in the control groups, 4 revealed the control groups outperformed the treatment groups, and 3 showed no significant differences. This ratio may challenge, to some extent, the results of those studies reviewed earlier in this chapter which reported the positive effects of cooperative learning in the Western context. It is a common finding in Western research (e.g. Johnson \& Johnson, 2009; Slavin, 2011) that cooperative learning provides greater achievement than competitive or individualistic learning. In summary, the benefits of cooperative learning have been shown in numerous studies in the Western context, while in the Asian context [including Vietnam], some studies show it is no better than, or worse than the lecture in its effects on students' learning.

The preceding review of literature shows that in comparison with traditional lecture-based teaching, cooperative learning generally appears to have a greater likelihood of improving students' long-term achievement, and their knowledge retention. However, the review also shows that almost all studies which supported the effectiveness of cooperative learning were conducted in the environment of Western education. Hence, it is less clear whether cooperative learning can be as successfully applied in Asian countries (e.g. Vietnam), in which social, religious, educational and cultural systems are likely to be different from those of Western countries (Nguyen et al., 2009b; 
Thanh-Pham et al., 2008). In addition, very few research studies have investigated the effects of cooperative learning on students' learning in Vietnam. As reported in our previous papers (Tran \& Lewis, 2012a\&b), only one study (Luu, 2010) was located which utilized a pre-test and post-test with the control group design to investigate Vietnamese tertiary students' achievement when taught by cooperative learning. It reports its effectiveness, but does not discuss longer term achievement. Until now no known study has examined the relationship between cooperative learning and students' knowledge retention in the setting of VHEI. An investigation of the empirical evidence associated with the benefits of cooperative learning in other education levels in both Western and Asian countries, and the current reality of the lecture-based teaching in VHEI support an investigation of the effectiveness of cooperative learning on students' knowledge retention. A strong relationship between cooperative learning methods and higher achievement as well as greater long-term achievement shown in the literature supports the hypothesis that in general: "students who are taught by jigsaw learning will have greater retention of information taught in the MAE (Management of Administration and Education) course than those taught through lecture-based teaching.

\section{Method}

\subsection{Sample}

As noted in our previous reports (Tran \& Lewis, 2012a\&b), an experimental study was undertaken, using the Pre-test-Post-test Non-equivalent Comparison-Group Design, to test the cause and effect relationship between a treatment variable (jigsaw learning pedagogy) and the students' achievement and attitudes to cooperative learning, although the outcome of relevance to this paper is knowledge retention.. This study used a sample of 80 final-year mathematics students comprising 32 females and 48 males in the Faculty of Education at An Giang University in Vietnam. The 80 students were matched into two groups of 40, based on the variables of age, gender and GPA scores. In the experimental group of 40 students, there were 24 males and 16 females with a mean age of 21.50 and a mean GPA score of 6.45, while in the control group of 40, there were 24 males and 16 females with a mean age of 21.53, and a mean GPA score of 6.51

\subsection{Experimental Procedure}

As described in our papers, the experimental procedure involved a number of steps. Prior to the beginning of the academic year of 2010-2011, an outline of the research project was given to 80 students in two mathematics classes, who enrolled a Management of Administration and Education course. All 80 students from these two classes voluntarily agreed to participate in this study. As stated above, they were placed into two groups of 40, matched on age, gender and GPA scores. A pre-test on MAE knowledge was administered to the control and experimental groups before the treatment to validate equivalence of MAE knowledge between the two groups. The results showed no significant differences $(p>.05)$ between groups' GPA scores or their scores on the content related pre-test. One group was randomly chosen to receive lecture-based teaching and acted as the control group, and the other received jigsaw learning and acted as the experimental group.

In the control group, students learned the conventional MAE content as a result of lecture-based teaching in logical steps, and they worked as a whole class group, with some time spent on questions and general class discussions. The instructor's role was one of information transmitter. The main interaction was to be between the teacher and the students. In the experimental group, the instructor applied the jigsaw technique, implementing the following eight steps. First, the objectives of the subject matter were identified. Second, the learning materials were organized. Third, ten home groups of four students were formed (Figure 1), and eight jigsaw groups of five were formed from the ten home groups (Figure 2). For example, students (A1, A2, A3, and A4) comprised one of the home groups, and students (A1, B1, C1, D1, and E1) comprised a jigsaw group. Fourth, the instructor explained how the entire unit is structured and organized. The MAE content matter comprised six units. Each unit was divided into four independent subunits and each was given to a different member of a home group to study. Each student then read to the other home group members the title of the subunit assigned to him or her, so that all of the group members become acquainted with the sequence of the learning material. Fifth, when students understood the lesson structure, they were asked to move to new groups called jigsaw groups. There were eight jigsaw groups of five students formed from the ten home groups. Sixth, the instructor had students help one another learn their same specialist sections. Seventh, after students had helped each other to learn their learning materials, they were requested to return to their home groups to teach other members what they learned from their experience in the jigsaw groups. Finally, students presented their understanding of the entire unit to the whole class, and subsequently the instructor gave feedback about the quality of their presentations. This whole process was repeated six times, once for each unit of work. Throughout the study, both groups were taught by the researcher, an MAE instructor with 11 years of teaching experience. The experimental group was conducted on Mondays, while the control group was on Tuesdays. Both groups covered the same MAE content 
and received MAE instruction for the same amount of time in the mornings, and in the same room. All students in both groups participated in one instructional session of 180 minutes per week for each unit over the six weeks. After the treatment, both groups took a post-test immediately and a delay test a month after the instruction. The same test was given on both occasions.

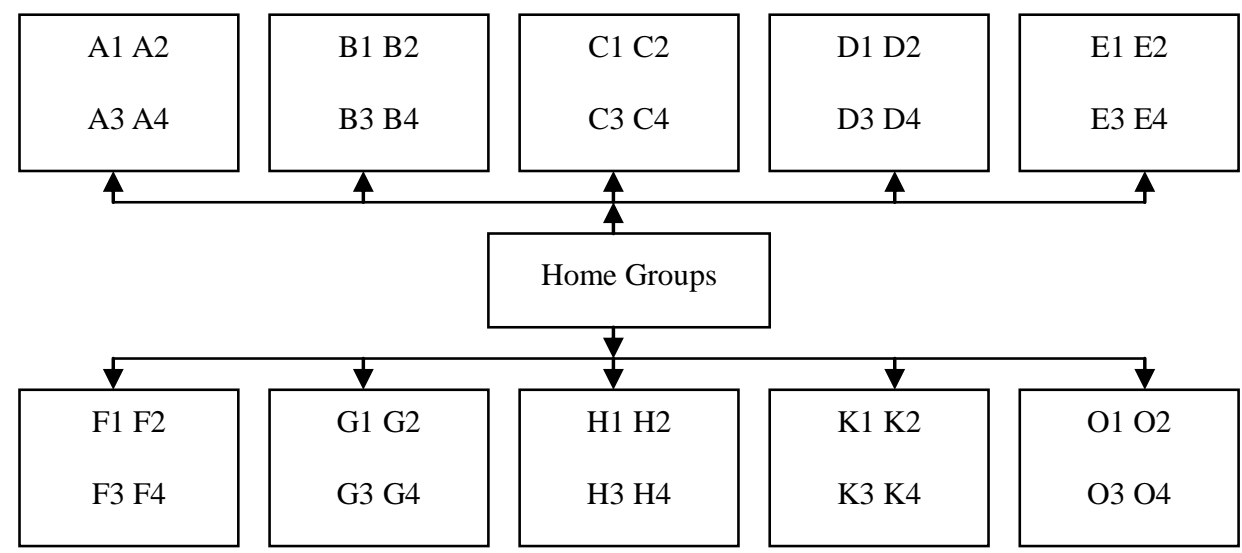

Figure 1. Home groups

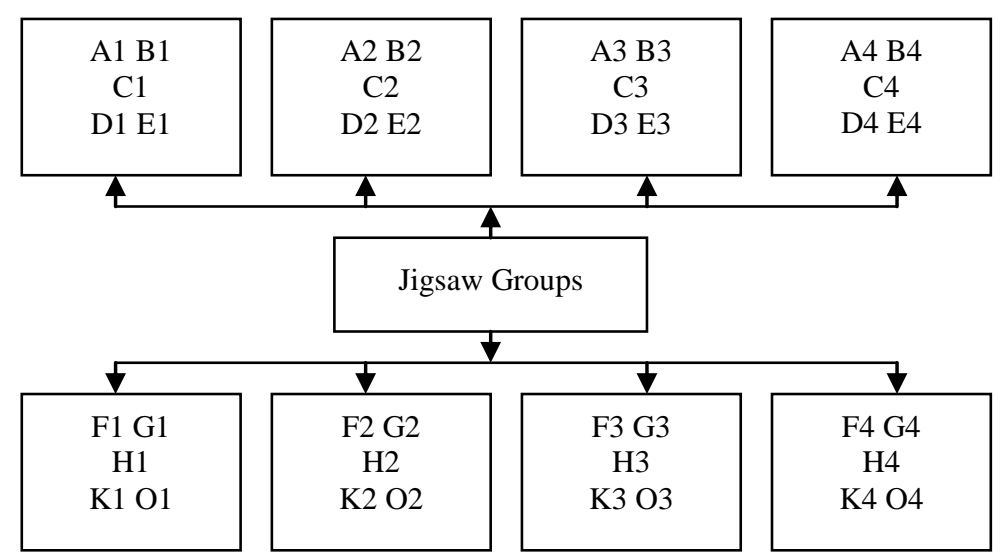

Figure 2. Forming jigsaw groups from home groups

\subsection{Instrumentation}

As described in our report (Tran \& Lewis, 2012a), a pre-test (30 items) on the MAE knowledge was used to validate the equivalence of the academic ability of the groups before the treatment. All questions focused on the students' general knowledge of subjects addressed in the MAE. A post-test also comprised 30 items, focusing on the content of the MAE course was used to measure achievement immediately after the treatment ended. A delay test (the same as the post-test) was used to measure the percentage of scores the students realized after one month. All items in both pre-test and post-test were presented in a multiple-choice format. Each item had four alternative choices for the correct answer. The maximum mean score of each test is 10 . Using a KR 20 coefficient, the reliability of the pre-test was .71, and was .86 for the post-test.

One survey questionnaire was administered to both the experimental and control groups after the treatment as part of this study to measure students' perception of the instructor and instruction, in both the experimental and control groups. It was used to validate the fact that there was a difference in treatment as planned. This survey, containing 27 items, measured a range of elements of the instructor and the instruction offered to students in both groups. Of these items, there were some which were meant to be equally applicable to the instructor and instruction in both groups, and others which focused on the extent to which students experienced techniques associated will cooperative group-work. In contrast, there were other items designed to measure techniques associated with direct instruction. For each item, respondents indicated on a five point scale the frequency with which it occurred by choosing from Never (N), Hardly Ever (HE), Sometimes (S), Often (O), and Very Often (VO). Positively worded Items are scored 1, 2, 3, 4 and 5, respectively, for the responses $\mathrm{N}, \mathrm{HE}, \mathrm{S}, \mathrm{O}$ and $\mathrm{VO}$. In contrast, negatively oriented items are scored in the opposite way. 


\section{Results}

The 27 items of the instructor and instruction questionnaire were subjected to principle components analysis (PCA). Using Catell's (1966) Scree test and after consideration of the Scree test and the results of a parallel Monte Carlo factor analysis, it was decided to retain four components for further investigation. All but two items displayed positive component loadings (greater than 0.4 ) on one and only one of the four components. Item 11 and 12, each loaded at greater than 0.4 on two components, and were placed into the component on which they had the higher loading (Table 1).

Table 1. Pattern matrix for instructor and instruction items

$(\mathrm{n}=80)$

\begin{tabular}{|c|c|c|c|c|}
\hline \multirow{2}{*}{ Instructor and Instruction Items } & \multicolumn{4}{|c|}{ Component } \\
\hline & 1 & 2 & 3 & 4 \\
\hline 2. teacher organized the lesson well. $(+)$ & $.905 *$ & -.001 & -.031 & .094 \\
\hline 24. teacher asked questions to check students' understanding. $(+)$ & .880 & -.034 & -.033 & .012 \\
\hline 27. teacher explained, using examples that students could understand.(+) & .836 & -.042 & .012 & .060 \\
\hline 26. students were encouraged to express their ideas to the teacher. $(+)$ & .820 & -.016 & .031 & .144 \\
\hline 25. students understood the lesson well. (+) & .780 & -.025 & -.110 & -.048 \\
\hline 16. teacher did not go too fast. $(+)$ & .777 & .035 & -.085 & -.019 \\
\hline 23. teacher gave satisfactory answers to students' questions. $(+)$ & .775 & -.011 & -.035 & -.101 \\
\hline 17. teacher did not go too slowly. $(+)$ & .742 & .114 & -.134 & -.111 \\
\hline 4. teacher was supportive of students. $(+)$ & 690 & .019 & .249 & -.191 \\
\hline 5. teacher appeared friendly. $(+)$ & .506 & -.026 & .092 & -.268 \\
\hline 7. students exchanged information. $(+)$ & .137 & .729 & .011 & .014 \\
\hline 1. teacher lectured. (-) & -.082 & -.714 & .070 & -.162 \\
\hline 14. students worked individually. (-) & .037 & -.649 & .180 & .160 \\
\hline 22. students discussed the learning material with other students. $(+)$ & -.153 & .633 & .158 & .121 \\
\hline 15. students listened attentively to lecture. (-) & -.029 & -.631 & .200 & -.118 \\
\hline 18. students watched PowerPoint presentation. (-) & .169 & -.596 & .187 & .088 \\
\hline 11. students helped each other. $(+)$ & .044 & .498 & .408 & .046 \\
\hline 3. students learned in groups. $(+)$ & .107 & .487 & .138 & -.200 \\
\hline 6. students taught each other. $(+)$ & -.013 & .431 & .392 & -.218 \\
\hline 20. teacher spoke clearly. $(+)$ & .031 & -.076 & .802 & .115 \\
\hline 21. teacher made the lesson interesting. $(+)$ & -.017 & -.096 & .719 & .047 \\
\hline 13. teacher made the information easy for students to understand. $(+)$ & -.052 & -.158 & .716 & -.105 \\
\hline 19. students were encouraged to ask questions. $(+)$ & -.151 & .083 & .667 & -.235 \\
\hline 9. students were pleased with how much they were learning. $(+)$ & .158 & .168 & .142 & -.822 \\
\hline 10. teacher seemed knowledgeable. $(+)$ & .181 & .095 & .086 & -.813 \\
\hline **12. teacher discussed the learning material with his students. $(+)$ & .216 & .429 & .307 & .514 \\
\hline 8. teacher seemed enthusiastic about the subject. $(+)$ & .290 & -.165 & .085 & -.466 \\
\hline
\end{tabular}

*Factor loadings greater than 0.4 are reported in bold print

** This item was omitted on the fourth component

Four components were consequently constructed on the basis of the results of the components analysis (Table 1). The first component, called Generic Teaching Skills (GTS), contained 10 items (e.g. Teacher organized the lesson well; Teacher asked questions to check students' understanding; Teacher gave satisfactory answers to students' questions). The second component combining 9 items was called Student-Centered Learning (SCL). Four of these items which emphasized teacher-centered instruction (e.g. Teacher lectured; Students watched Powerpoint presentation) loaded negatively [-] on the second component which in general contained items focusing on group work activities (e.g. Students exchanged information; Students taught each other). The third component, Engagement with Learning (EL), comprised 4 items (e.g. Teacher spoke clearly; Teacher made the information easy for students to 
understand). The fourth component comprised 4 items (e.g. Teacher seemed knowledgeable; Teacher seemed enthusiastic about the subject) was called Powerful Teacher (PT). The students' responses $(\mathrm{n}=80)$ to the four components were checked for internal consistency by computing respective Cronbach Alpha coefficients, and only one item (item 12) was removed from consideration as its removal increased the magnitude of the Cronbach Alpha coefficient of the fourth component. Table 2 below reports the means, standard deviations, and Cronbach Alpha coefficient of internal consistency for the components.

Table 2. Techniques of the instructor and instruction

Experimental Group Control Group

\begin{tabular}{lllllllll} 
Variable & \multicolumn{2}{c}{$(\mathrm{n}=40)$} & & \multicolumn{2}{c}{$(\mathrm{n}=40)$} & & & \\
\cline { 2 - 3 } & Mean & S.D. & & Mean & S.D. & Total & Alpha & No of Items \\
GTS & 3.93 & .75 & & 3.90 & .81 & 3.91 & .92 & 10 \\
SCL & 3.32 & .27 & & 2.62 & .21 & 2.97 & .77 & 9 \\
EL & 3.80 & .68 & & 3.78 & .53 & 3.80 & .75 & 4 \\
PT & 3.79 & .66 & & 3.81 & .74 & 3.80 & .70 & 3 \\
\hline
\end{tabular}

Key: $1=$ Never; 2 = Hardly ever; $3=$ Sometimes; $4=$ Often; $5=$ Very often

The relationships between the four components of the instructor and instruction were investigated using Pearson product-moment coefficient. The results shows that there were moderate, positive correlations between the PT and EL scales $(\mathrm{r}=.37, \mathrm{p}<.005)$, and GTS $(\mathrm{r}=.43, \mathrm{p}<.001)$. However, there was no significant relationship between SCL and PT $(r=.06, p>.05)$, or between EL $(r=.05, p>.05)$, and GTS $(r=.07, p>.05)$. In this study items on the three scales, powerful teacher, engaging with learning and generic teaching skills, were considered to be addressing generic qualities of the instructor, namely and respectively (1) students' perceptions of the professional capacity of the instructor, (2) the instructor's efforts to facilitate students' appreciation and understanding of the learning material, and (3) generic teaching skills of the instructor. The student-centered learning scale was considered the aspect of the instruction, which focused on some activities of cooperative group processes, and some activities of direct instruction.

\subsection{Perceptions of the Instructor}

To test if students' perceptions of the generic qualities of their instructor differ, according to whether they were taught by jigsaw learning or lecture-based teaching, a one-way between-groups multivariate analysis of variance (MANOVA) was performed. The results shows that there was a statistically significant difference between the groups on the combined dependent variables, $\mathrm{F}_{(4,75)}=39.53, \mathrm{p}<.000$, Wilks' Lamda $=.68$, partial eta squared $\left(\mu^{2}\right)=.67$. When the results of univariate ANOVAs for dependent variables were considered separately, there was a statistically significant difference between the experimental group and control group on the $S C L$ variable $\left(\mathrm{F}_{(1,78)}=160.67, \mathrm{p}<.001, \mu^{2}=.67\right)$. However, there was non-significant difference between the experimental group and control group on the $P T$ variable, $\left(\mathrm{F}_{(1,78)}=.02, \mathrm{p}>.05, \mu^{2}=.00\right), E L\left(\mathrm{~F}_{(1,78)}=.01, \mathrm{p}>.05, \mu^{2}=.00\right)$, and $G T S\left(\mathrm{~F}_{(1,78)}=.03, \mathrm{p}>.05, \mu^{2}=.00\right)$ (Table 3$)$.

Table 3. Results obtained from Tests of Between-Subjects Effects

\begin{tabular}{|c|c|c|c|c|c|c|c|c|}
\hline \multirow[t]{2}{*}{ Scales } & \multicolumn{2}{|c|}{$\begin{array}{c}\text { Experimental group } \\
(\mathrm{n}=40)\end{array}$} & \multicolumn{2}{|c|}{$\begin{array}{c}\text { Control group } \\
(\mathrm{n}=40)\end{array}$} & \multirow[b]{2}{*}{$\begin{array}{l}\text { Mean } \\
\text { difference }\end{array}$} & \multirow[b]{2}{*}{ F-value } & \multirow[b]{2}{*}{ Prob $^{a}$} & \multirow[b]{2}{*}{$\begin{array}{l}\text { Partial } \\
\text { Eta } \\
\text { Squared }\end{array}$} \\
\hline & Mean & S.D. & Mean & S.D. & & & & \\
\hline PT & 3.79 & .66 & 3.81 & .74 & .02 & .02 & .891 & .00 \\
\hline SCL & 3.32 & .27 & 2.62 & .21 & $.70^{*}$ & 160.67 & .000 & .67 \\
\hline EL & 3.80 & .68 & 3.79 & .61 & .01 & .01 & .892 & .00 \\
\hline TS & 3.92 & .75 & 3.89 & .81 & .03 & .03 & .865 & .00 \\
\hline
\end{tabular}

"The mean difference is significant at the .05 level.

a. Adjustment for multiple comparisons: Bonferroni.

An inspection of mean scores in Table 3 indicates that students' perceptions of the generic quality of the instructor in both groups are similar. The magnitude of differences in the two mean scores between the experimental group and control group on the three variables was very small, .01 scale point for the $P T$ scale,.02 for the $E L$ scale and .03 for the GTS scale. Specifically, the results (Table 4) indicate that, on average, students in both the experimental and control groups felt that the instructor was knowledgeable and enthusiastic about the subject, and they were satisfied 
with how much they were learning. The results in Table 3 show students perceived these qualities as present a little less than 'Often' [mean of 3.79 in the experimental group, and 3.81 in the control group]. Secondly, students believed that the instructor in both the experimental group and control group generally made the MAE lessons interesting, and made the information easy for students to understand, spoke clearly, and encouraged students to ask the questions. The results in Table 3 show that these activities also occurred a little less than 'Often' [mean of 3.80 in the experimental group, and 3.79 in the control group]. In addition, students in both the experimental group and control group perceived that the instructor generally organized the lesson well, asked questions to check students' understanding, explained and used examples than students could understand, encouraged students to express their ideas to the teacher, helped students understand the lesson well, gave satisfactory answers to students' questions, did not go too fast nor too slowly, supported students to learn, and appeared friendly. The results reported in Table 3 show that all of these occurred in both groups a little less than 'Often' [mean of 3.92 in the experimental group, and 3.89 in the control group]. In summary, students' positive perceptions of these three generic instructional factors indicate that the instructor who taught the MAE course to both groups was not biased against students in the control group and provided quality instruction.

Table 4. The generic quality of the instructor

Items of Generic Teaching Skills scale

\begin{tabular}{|c|c|c|c|c|c|}
\hline No. & Items & Group & $\mathrm{N}$ & Mean & Std. Deviation \\
\hline \multirow{2}{*}{1.} & teacher organized the lesson well. & 1 & 40 & 4.25 & .809 \\
\hline & & 2 & 40 & 4.18 & .958 \\
\hline \multirow[t]{2}{*}{2.} & teacher asked questions to check students' understanding. & 1 & 40 & 4.03 & .947 \\
\hline & & 2 & 40 & 4.13 & .966 \\
\hline \multirow[t]{2}{*}{3.} & teacher explained, using examples that students could understand. & 1 & 40 & 4.05 & 1.037 \\
\hline & & 2 & 40 & 4.03 & .862 \\
\hline \multirow[t]{2}{*}{4.} & students were encouraged to express their ideas to the teacher. & 1 & 40 & 3.98 & .891 \\
\hline & & 2 & 40 & 3.95 & .932 \\
\hline \multirow[t]{2}{*}{5.} & students understood the lesson well. & 1 & 40 & 3.85 & .975 \\
\hline & & 2 & 40 & 3.98 & .768 \\
\hline \multirow[t]{2}{*}{6.} & teacher gave satisfactory answers to students'questions. & 1 & 40 & 3.98 & .832 \\
\hline & & 2 & 40 & 3.95 & .959 \\
\hline \multirow[t]{2}{*}{7.} & teacher did not go too fast. & 1 & 40 & 3.53 & 1.339 \\
\hline & & 2 & 40 & 3.33 & 1.421 \\
\hline \multirow[t]{2}{*}{8.} & teacher did not go too slowly. & 1 & 40 & 3.85 & 1.406 \\
\hline & & 2 & 40 & 3.58 & 1.412 \\
\hline & teacher was supportive of students. & 1 & 40 & 3.95 & .876 \\
\hline & & 2 & 40 & 3.93 & .797 \\
\hline & teacher appeared friendly. & 1 & 40 & 3.83 & .781 \\
\hline & & 2 & 40 & 3.95 & .904 \\
\hline
\end{tabular}

Items of Engaging with Learning scale

$\begin{array}{llllll} & \text { teacher spoke clearly. } & 1 & 40 & 3.93 & .859\end{array}$

$\begin{array}{lllll} & 2 & 40 & 3.90 & .928\end{array}$

2. teacher made the information easy for students to understand. $\begin{array}{llllll}1 & 40 & 3.70 & & 823\end{array}$

3. teacher made the lesson interesting. $\quad \begin{array}{lllll} & 40 & 3.83 & .658\end{array}$

$\begin{array}{lllll}3 . & 1 & 40 & 3.83 & .847\end{array}$

4. students were encouraged to ask questions. $\quad \begin{array}{lllll}1 & 40 & 3.78 & .800\end{array}$

\begin{tabular}{llllll} 
& 2 & 40 & 3.65 & .580 \\
\hline
\end{tabular}

Items of Powerful Teacher scale

\begin{tabular}{llllll}
\hline 1. & teacher seemed knowledgeable. & 1 & 40 & 3.73 & .905
\end{tabular}

2. $\quad$ teacher seemed enthusiastic about the subject. $\quad \begin{array}{lllll}1 & 40 & 3.65 & .770\end{array}$

$\begin{array}{llll}2 & 40 & 3.88 & .911\end{array}$

3. $\quad$ students were pleased with how much they were learning. $\quad \begin{array}{lllll}1 & 40 & 3.88 & .911\end{array}$

$\begin{array}{llll}2 & 40 & 3.90 \quad .810\end{array}$


Items of Generic Teaching Skills scale

\begin{tabular}{|c|c|c|c|c|c|}
\hline No. & Items & Group & $\mathrm{N}$ & Mean & Std. Deviation \\
\hline \multirow[t]{2}{*}{1.} & teacher organized the lesson well. & 1 & 40 & 4.25 & .809 \\
\hline & & 2 & 40 & 4.18 & .958 \\
\hline \multirow[t]{2}{*}{2.} & teacher asked questions to check students'understanding. & 1 & 40 & 4.03 & .947 \\
\hline & & 2 & 40 & 4.13 & .966 \\
\hline \multirow[t]{2}{*}{3.} & teacher explained, using examples that students could understand. & 1 & 40 & 4.05 & 1.037 \\
\hline & & 2 & 40 & 4.03 & .862 \\
\hline \multirow[t]{2}{*}{4.} & students were encouraged to express their ideas to the teacher. & 1 & 40 & 3.98 & .891 \\
\hline & & 2 & 40 & 3.95 & .932 \\
\hline \multirow[t]{2}{*}{5.} & students understood the lesson well. & 1 & 40 & 3.85 & .975 \\
\hline & & 2 & 40 & 3.98 & .768 \\
\hline \multirow[t]{2}{*}{6.} & teacher gave satisfactory answers to students' questions. & 1 & 40 & 3.98 & .832 \\
\hline & & 2 & 40 & 3.95 & .959 \\
\hline \multirow[t]{2}{*}{7.} & teacher did not go too fast. & 1 & 40 & 3.53 & 1.339 \\
\hline & & 2 & 40 & 3.33 & 1.421 \\
\hline \multirow[t]{2}{*}{8.} & teacher did not go too slowly. & 1 & 40 & 3.85 & 1.406 \\
\hline & & 2 & 40 & 3.58 & 1.412 \\
\hline \multirow[t]{2}{*}{9.} & teacher was supportive of students. & 1 & 40 & 3.95 & .876 \\
\hline & & 2 & 40 & 3.93 & .797 \\
\hline \multirow[t]{2}{*}{10.} & teacher appeared friendly. & 1 & 40 & 3.83 & .781 \\
\hline & & 2 & 40 & 3.95 & .904 \\
\hline \multicolumn{6}{|c|}{ Items of Engaging with Learning scale } \\
\hline \multirow[t]{2}{*}{1.} & teacher spoke clearly. & 1 & 40 & 3.93 & .859 \\
\hline & & 2 & 40 & 3.90 & .928 \\
\hline \multirow[t]{2}{*}{2.} & teacher made the information easy for students to understand. & 1 & 40 & 3.70 & .823 \\
\hline & & 2 & 40 & 3.88 & .607 \\
\hline \multirow[t]{2}{*}{3.} & teacher made the lesson interesting. & 1 & 40 & 3.83 & .958 \\
\hline & & 2 & 40 & 3.73 & .847 \\
\hline \multirow[t]{2}{*}{4.} & students were encouraged to ask questions. & 1 & 40 & 3.78 & .800 \\
\hline & & 2 & 40 & 3.65 & .580 \\
\hline \multicolumn{6}{|c|}{ Items of Powerful Teacher scale } \\
\hline \multirow[t]{2}{*}{1.} & teacher seemed knowledgeable. & 1 & 40 & 3.73 & .905 \\
\hline & & 2 & 40 & 3.90 & .810 \\
\hline \multirow[t]{2}{*}{2.} & teacher seemed enthusiastic about the subject. & 1 & 40 & 3.65 & .770 \\
\hline & & 2 & 40 & 3.88 & .911 \\
\hline 3. & students were pleased with how much they were learning. & 1 & 40 & 3.88 & .911 \\
\hline
\end{tabular}

1.Experimental group

2. Control group

Key: 1 = Never; 2 = Hardly ever; 3 = Sometimes; 4 = Often; 5 = Very often

\subsection{Perceptions of the Instruction}

Having established that the instructor who taught the MAE course to both groups was not biased against students in the control group, it was timely to test the validity of the treatment by determining if students taught by jigsaw learning perceive more frequent use of cooperative group processes and less frequent use of direct instruction during classes than those taught through lecture-based teaching. As reported earlier, there was a statistically significant difference between the experimental group and control group on the $S C L$ variable $\left(\mathrm{F}_{(1,78)}=160.67, \mathrm{p}<.001, \mu^{2}\right.$ $=.67)$. The partial eta squared value $\left(\mu^{2}=.67\right)$ implies that $67 \%$ per cent of the variance in student-centered learning scores is explained by group membership. The results indicate that students in the cooperative learning group perceived more frequent use of cooperative group processes, and less frequent use of direct instruction. An inspection of mean scores in Table 4 indicates that the difference in the two mean scores of 0.7 between the experimental and control group on the student-centered learning variable was approximately 3 within group SDs and therefore large. Inspection of the results (Table 5) reveals that, on average, students in the experimental group felt that the instruction was more cooperative and more student-centered, and less teacher-centered than did those in the 
control group. More particularly, students in the treatment group reported that they learned more frequently in groups, taught each other, exchanged information, helped each other, and discussed the learning material with other students. These aspects of cooperative learning occurred between 'Sometimes' and 'Often' [3.58]. They also perceived less working individually, listening attentively to lecture, watching PowerPoint presentations and lecturing. These aspects of teacher-centered instruction occurred between a little less than 'Sometimes' [2.99]. In contrast, the data indicates that students in the control group saw more working individually, listening attentively to lecture, watching PowerPoint presentations, and lecturing. These activities happened a little less than 'Often' [3.91]. They also perceived less learning in groups, teaching each other, exchanging information, helping each other, and discussing the learning material with other students. These activities happened 'Sometimes' [3.05]. It is significant to note that the lecture treatment was not so extreme as to create a 'straw man' stereotype but it also had some student-centered activities. Similarly, there was some teacher instruction perceived in the cooperative learning classroom. This is because both groups comprised students enrolled in a university program and their progress was dependent upon quality instruction which required that the instruction not become too extreme in mode of presentation. Nevertheless the students' perceptions reported above clearly indicate significantly more cooperative learning, and students teaching each other in the experimental group. Having validated the treatment, it was time to test its impact on students' knowledge retention.

Table 5. The instruction

\begin{tabular}{|c|c|c|c|c|c|c|}
\hline No. & Items & Group & $\mathrm{N}$ & Mean & $\begin{array}{c}\text { Std. } \\
\text { Deviation }\end{array}$ & $\begin{array}{l}\text { Cohen's } \\
\text { d value }\end{array}$ \\
\hline \multirow[t]{2}{*}{1.} & teacher lectured (-). & 1 & 40 & 2.83 & .594 & \multirow{2}{*}{2.14} \\
\hline & & 2 & 40 & 3.98 & .480 & \\
\hline \multirow[t]{2}{*}{2.} & students exchanged information. & 1 & 40 & 3.73 & .452 & \multirow{2}{*}{1.81} \\
\hline & & 2 & 40 & 3.08 & .267 & \\
\hline \multirow[t]{2}{*}{3.} & students discussed the learning material with other students. & 1 & 40 & 3.73 & .506 & \multirow{2}{*}{1.42} \\
\hline & & 2 & 40 & 3.10 & .379 & \\
\hline \multirow[t]{2}{*}{4.} & students listened attentively to lecture (-). & 1 & 40 & 3.23 & .480 & \multirow{2}{*}{1.37} \\
\hline & & 2 & 40 & 4.00 & .641 & \\
\hline \multirow[t]{2}{*}{5.} & students watched Power Point presentation (-). & 1 & 40 & 2.80 & .853 & \multirow{2}{*}{1.10} \\
\hline & & 2 & 40 & 3.75 & .870 & \\
\hline \multirow[t]{2}{*}{6.} & students worked individually (-). & 1 & 40 & 3.10 & .841 & \multirow{2}{*}{.98} \\
\hline & & 2 & 40 & 3.93 & .859 & \\
\hline \multirow[t]{2}{*}{7.} & students learned in groups. & 1 & 40 & 3.50 & .641 & \multirow{2}{*}{.87} \\
\hline & & 2 & 40 & 3.00 & .506 & \\
\hline \multirow[t]{2}{*}{8.} & students taught each other. & 1 & 40 & 3.48 & .716 & \multirow{2}{*}{.70} \\
\hline & & 2 & 40 & 3.05 & .504 & \\
\hline \multirow[t]{2}{*}{9.} & students helped each other. & 1 & 40 & 3.48 & .751 & \multirow{2}{*}{.62} \\
\hline & & 2 & 40 & 3.03 & .577 & \\
\hline
\end{tabular}

1.Experimental group

2. Control group

Key: $1=$ Never; $2=$ Hardly ever; $3=$ Sometimes; $4=$ Often; $5=$ Very often

4.3 Academic Achievement

In our previous report (Tran \& Lewis, 2012a), the results of a one-way ANCOVA analysis with MAE pre-test scores as the covariate found significant differences $(\mathrm{p}<.05)$ in MAE post-test scores. This analysis showed that the post-test scores (adjusted for pre-test) of the experimental group $(\mathrm{M}=7.84, \mathrm{SD}=.75$ ), which was taught with cooperative learning, were higher than those of students in the control group $(\mathrm{M}=7.38, \mathrm{SD}=.92)$, which was taught with lecture-based teaching.

\subsection{Knowledge Retention}

As indicated above, a one-way between-groups analysis of covariance (ANCOVA) was conducted to compare the MAE delay test scores of two groups. The pre-test scores were also used as the covariate in this analysis. The resulting test for equality of adjusted means reported in Table 6 found a significant difference $\left(F_{(1,77)}=10.07, p\right.$ $\left.=.002, \mu^{2}=.48\right)$. The partial eta squared value $\left(\mu^{2}=.48\right)$ represents $48 \%$ per cent of the variance in delay test scores explained by group membership. There was also a medium relationship between the pre-test scores and delay test scores as indicated by a partial eta squared value of .34. Inspection of the means in Table 6 indicates that the adjusted 
means for the experimental group delay test $(\mathrm{M}=7.80, \mathrm{SD}=.66)$ is significantly higher than that of the control group $(\mathrm{M}=7.32, \mathrm{SD}=.94)$. Results indicated that students in the experimental group had higher overall delay test scores in the MAE course $(\mathrm{p}=<.05)$ than those the control group. Although a statistically significant difference on the mean scores of the delay test between two groups was found, the actual difference in the two mean scores between the experimental group and control group on delay test represented a moderate effect size of approximately 0.5 .

Table 6. Results obtained from Tests of Between-Subjects Effects

\begin{tabular}{|c|c|c|c|c|c|c|c|c|c|}
\hline \multirow{2}{*}{ Variable } & \multicolumn{2}{|c|}{$\begin{array}{c}\text { Experimental group } \\
(\mathrm{n}=40)\end{array}$} & \multicolumn{2}{|c|}{$\begin{array}{r}\text { Control group } \\
(\mathrm{n}=40) \\
\end{array}$} & \multirow[b]{2}{*}{ Total } & \multirow[b]{2}{*}{$\begin{array}{l}\text { Mean } \\
\text { difference }\end{array}$} & \multirow[b]{2}{*}{$\begin{array}{l}\text { F-valu } \\
\mathrm{e}\end{array}$} & \multirow[b]{2}{*}{ Prob. } & \multirow[b]{2}{*}{$\begin{array}{l}\text { Partial } \\
\text { Eta } \\
\text { Squar } \\
\text { ed }\end{array}$} \\
\hline & Mean $^{\mathrm{b}}$ & S.D. & Mean $^{\mathrm{b}}$ & S.D. & & & & & \\
\hline Pre-test & 6.61 & .88 & 6.76 & .91 & 6.69 & .15 & .55 & .458 & .007 \\
\hline Post-test & $7.84^{\mathrm{a}}$ & .75 & $7.38^{\mathrm{a}}$ & .92 & 7.61 & $.46^{*}$ & 8.43 & .005 & .47 \\
\hline Delay test & $7.80^{\mathrm{a}}$ & .66 & $7.32^{\mathrm{a}}$ & .94 & 7.56 & $.47^{*}$ & 10.07 & .002 & .48 \\
\hline
\end{tabular}

"The mean difference is significant at the .05 level.

a. Covariate appearing in the model is evaluated at the following value: pre-test $=6.69$.

b. Maximum mean scores: 10 .

To examine the variation of post-test scores and delay test scores for each group, a paired-samples t-test was performed. Results show that in the treatment group there was a non-significant decrease in scores from the post-test $(\mathrm{M}=7.80, \mathrm{SD}=.75)$ to delay test $(\mathrm{M}=7.76 ; \mathrm{SD}=.67), \mathrm{t}(39)=1.03, \mathrm{p}>.05$ (two-tailed). The mean decrease was .04 with a $95 \%$ confidence interval ranging from -.04 to .12. The eta squared statistic (.02) indicated a small effect size. Similarly, in the control group there was a non-significant decrease in scores from the post-test $(\mathrm{M}=7.42$, $\mathrm{SD}=.92)$ to delay test $(\mathrm{M}=7.36 ; \mathrm{SD}=.94), \mathrm{t}(39)=1.16, \mathrm{p}>.05$ (two-tailed). The mean decrease was .06 with a $95 \%$ confidence interval ranging from -.04 to .15. The eta squared statistic (.03) indicated a small effect size. Results of these analyses show that both the cooperative learning group and lecture-based teaching group retained nearly all of what they had learned from the MAE course (Figure 3). In summary therefore, results indicate that a month after the experiment, both the treatment group and control group had a similar rate of knowledge retention on achievement test. In the cooperative learning group, the actual difference in the two mean scores on the post-test and delay test was .04. In the lecture group, this difference was .06. In other words, both groups retained nearly of what they had learned (approximately 99 percent).

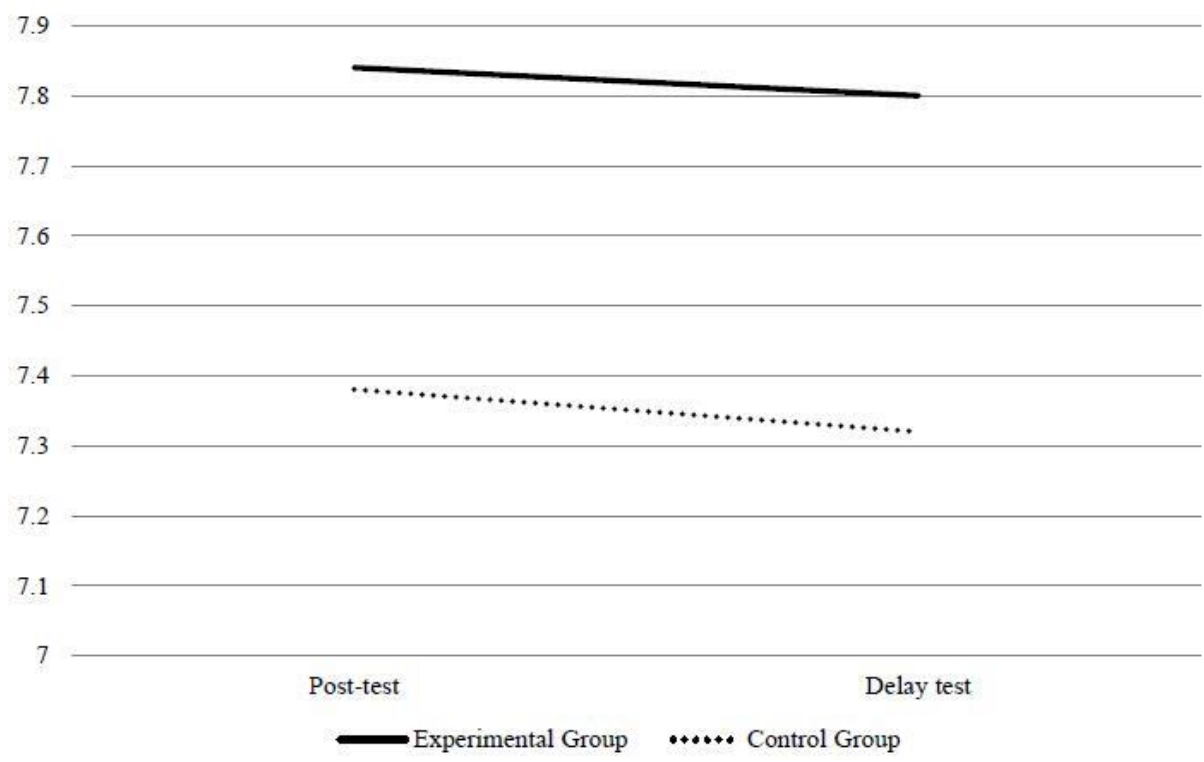

Figure 3. Mean scores of Post-test and Delay-test 


\section{Discussion}

In this study, the students who learned via cooperative learning had greater long-term achievement than did those taught by lecture, with an effect size of .48. The results also indicate that a month after the experiment, students in both groups had similar knowledge retention from the achievement post-test. A month after the experiment they retained nearly all of what they had learned (approximately 99 percent) over the six weeks of the instruction. Therefore, the hypothesis that students in the jigsaw group retained more of the information than did those taught through lectures was rejected.

The study revealed evidence that supports the positive impact of cooperative learning on the long-term achievement of a group of Vietnamese tertiary students. In this study students in the cooperative learning group, which involved higher participation in the process of learning, had greater long-term achievement on the MAE delay test than students in the comparison group because they were equipped with skills in terms of teaching others and elaborating ideas on the concept taught in the learning process. This finding validates the results of some earlier studies (Johnson \& Johnson, 2005; Tanel \& Erol, 2008; Moore, 2008; Sahin, 2010) which indicate that cooperative learning promotes greater long-term achievement than individual learning at least 24 hours after the treatment. In addition, the results of this study validate the jigsaw learning treatment in the experimental group. Vietnamese tertiary students' perceptions of the instruction in the experimental group were compatible with the nature of cooperative learning in which students work together to maximize their own learning and others' learning (Slavin, 2011). As described in the Method section in this study, the jigsaw process in the treatment group required students to read and learn the assigned learning materials, to move from home groups to jigsaw groups to help each other to learn their assigned learning materials, and back to teach other members what they learned from their experience in the jigsaw groups. Consequently, skills were enhanced by the exchanging and sharing of information, and the cooperative discussion held, by students in the group. Since every student in the treatment group was responsible for a small part of the MAE learning material and had to teach it to other members of the group, this feeling of having a specific responsible role enhanced students' central position in the process of constructing knowledge.

Furthermore, the greater long-term achievement of the treatment group was well supported by the students' perceptions of the instruction. First, the results show that there was a statistically significant difference $(\mathrm{p}<.001)$ between the experimental group and control group on the student-centered learning variable. Students taught by jigsaw learning perceived more frequent use of cooperative group processes and less frequent use of elements of lecture during the instruction than those taught through lecture-based teaching. Results indicate that the actual difference in the mean scores of the experimental group and control group on the student-centered learning variable was large and approximately 3 within group standard deviations [mean difference of .70]. Inspection of the results reveals that, on average, students in the experimental group felt that the instruction was more cooperative and more student-centered, and less teacher-centered than did those in the control group. As discussed earlier, teaching others and elaborating ideas were the main features of cooperative learning (Slavin, 2011). These techniques equipped students in the treatment group with the ability to associate the new knowledge with prior knowledge to detect relationships, and prepared the students for cognitive re-structure and elaborative rehearsal to enhance learning tasks (Sousa, 2006; Moore, 2008; Zakaria, et al., 2010; Webb, 2008). In the treatment group Vietnamese tertiary students believed that they had a deep understanding of the MAE course, and gained more knowledge from engaging in cooperative activities when they offered explanations to others or received explanations from others. This study shows that learning activities based on divided learning tasks, along with the students' personal involvement in the learning process, contributed to their gains in achievement on the delay test in the treatment group. As a result of the students' active participation, in the cooperative learning group they rehearsed the MAE learning material in a variety of ways, and mastered the learning material more effectively. It seems that learning activities based on group discussion, along with the students' personal involvement in the learning process, contributed to their long-term achievement. The results of this study are consistent with the findings of previous studies (Slavin, 2011; Sahin, 2010; Johnson \& Johnson, 2008; Tanel \& Erol, 2008; Webb, 2008; Moore, 2008) that indicate that cooperative learning results in greater long-term achievement than the traditional lecture-based teaching group.

However it is interesting and important to note that between the post-test and delay test scores, students in both the cooperative learning group and lecture-based teaching group retained nearly all of what they had learned from the MAE course. As noted earlier, students in both groups thought that the instructor had high professional capacity, in term of teaching skills, ability to engage students in learning, and ability to facilitate students' appreciation and understanding. An inspection of mean scores indicated that students' perceptions of the generic quality of the instructor in both groups are similar. For example, students in both the experimental group and control group thought that the instructor was knowledgeable, and enthusiastic about the subject, and they were satisfied with how much 
they were learning. In addition, in students' opinions the instructor in both the experimental group and control group apparently made the MAE lessons interesting, and made the information easy for students to understand, spoke clearly, and encouraged students to ask the questions. Furthermore, students in both the experimental group and control group perceived that the instructor organized the lesson well, asked questions to check students' understanding, explained and used examples than students could understand, encouraged students to express their ideas to the teacher, helped students understand the lesson well, gave satisfactory answers to students' questions, did not go fast, did not go slowly, supported students to learn, and appeared friendly. All of these activities of the instructor showed that even if jigsaw learning was used in the treatment group or lecture-based teaching was used in the control group, the instructor emphasized the development of understanding of concepts and principles rather than the recall of factual information or development of routine skills. This showed that the instruction in both groups focused on student understanding rather than memorization over the six weeks of instruction.

Taking this into account, it is helpful to take a closer look at the strict conditions under which the instructor operated in this study. Although jigsaw learning or lecture-based teaching was used in the different groups, the instructor, whether as facilitator in the experimental group or as transmitter in the control group, acted in accordance with an explicit set of principles, described in the Method section. In both groups he presented the general outline of the MAE learning materials in a short lecture about the MAE course, highlighting objectives, structure and content of each lesson, and the form of assessment for each lesson outcome, before jigsaw learning was employed in the experimental group, and lecture-based teaching was used in the control group during the six weeks of the experiment. This can only be done when the instructor has put the necessary work into structuring the content so that the learning activities are meaningful in both groups.

In this study, results show that lecture-based teaching helped Vietnamese tertiary students retain nearly all of what they had learned. They remembered approximately 99 percent of their post experiment knowledge when tested a month later on the delay test of achievement. This ratio validates, to some extent, the results of those studies reviewed earlier (Abu \& Flowers, 1997; Tanel \& Erol, 2008; Sahin, 2010, \& Wyk, 2010) which reported that students in both cooperative learning group and traditional teaching groups have a similar percentage of knowledge retention on the delay test of achievement. In this study, a possible explanation for the similarity in knowledge retention could be that Vietnamese tertiary students are very adept at learning meaningfully from lecture-based teaching. Nevertheless, although all students in the treatment group were accustomed to a teacher-centered style of learning environment, they could adapt to this new cooperative style of learning in six weeks of instruction in an Asian learning context. This finding supports those of some previous studies which report that Asian students [including Vietnamese students] are highly adaptive in accommodating to the style of teaching and learning they experience in Western education contexts (Biggs, 1996; Hofstede \& Hofstede, 2005; Nguyen, Terlouw, Pilot, \& Elliot, 2009). It therefore can be argued that learning styles are not culturally-based but contextual.

\section{Conclusion}

The results show that a month after learning via jigsaw grouping, Vietnamese tertiary students had greater long-term achievement on a delay test than did a similar group of Vietnamese students taught by lecture. Although all students in the treatment group were accustomed to a teacher-centered style of instruction, they could adapt to this new cooperative style of learning in six weeks of instruction in an Asian learning context. It can be argued therefore that Vietnamese students are highly adaptive in accommodating to a Western style of learning. Consequently it appears that learning styles are not culturally-based but contextual. However, results show that students in both groups had similar knowledge retention on a delay test of achievement. They retained nearly all of what they had learned over the six weeks of the instruction. Therefore, the hypothesis was rejected that students in the jigsaw group retained more of the learned information than did those taught through lecture. The findings show that Vietnamese tertiary students who were exposed to lecture could retain nearly all their learning, when the instructor is good and the learning materials are prepared well. However, this study has some limitations. Since both groups are taught by the same instructor over the six-week instruction, his teaching approach may have interacted with the treatment. Although students' perceptions of the quality of the instructor in both groups did not differ significantly on the measures of the quality of the instructor, the findings of this study should be replicated with different instructors teaching in two groups. As only a few research studies have investigated the effectiveness of cooperative learning in VHEI, the findings of this study are not sufficient to decide on the optimal use of cooperative learning at all levels of education in Vietnam. Thus, a series of further studies on cooperative learning in different subject areas at primary and secondary levels of Vietnamese education should be undertaken. This study showed that the effectiveness of cooperative learning on students is compatible with the requirements of teaching and learning innovation in VHEI. The findings provide Vietnamese tertiary teachers with more empirical support for promoting productive changes in 
teaching methods to improve student learning in the current wave of educational reform in VHEI. To promote the implementation of cooperative learning effectively, both lecturers and students in VHEI would need to undergo a training course in this kind of learning.

\section{References}

Abu, R., \& Flowers, J. (1997). The Effects of Cooperative Learning Methods on Achievement, Retention and Attitudes of Home Economics Students in North Carolina. Journal of Vocational and Technical Education, 13(2), 16-22.

Aronson, E., Blaney, N., Stepan, C., Sikes, J., \& Snapp, N. (1978). The jigsaw classroom. (2rd ed.). Beverley Hills, CA: Sage.

Ballantine, J., \& Larres, P. M. (2007). Cooperative learning: a pedagogy to improve students' generic skills? Education and Training, 49(2), 127-137. http://dx.doi.org/10.1108/00400910710739487

Beck, L. L., \& Chizhik, A. W. (2008). An experimental study of cooperative learning in CS1. In Proceedings of the 39th SIGCSE technical symposium on Computer science education (pp. 205-209). New York: ACM. http://dx.doi.org/10.1145/1352135.1352208

Biggs, J. (1996). Western misconceptions of the Confucian-heritage learning culture. In D. A. Watkins \& J. B. Biggs (Eds.), The Chinese Learner: Cultural, Psychological and Contextual Influences (pp. 45-67). Hong Kong: The Central Printing Press.

Cheng, H. (2006). A comparison between cooperative learning and traditional, whole-class methods-teaching English in a Junior College. Academic Journal of Kang-Ning, 3, 69-82.

Chianson, M. M., Kurumeh, M. S., \& Obida, J. A. (2010). Effect of cooperative learning strategy on students' retention in circle geometry in secondary schools in Benue State, Nigeria. American Journal of Scientific and Industrial Research, 2(1), 33-36. http://dx.doi.org/10.5251/ajsir.2011.2.1.33.36

Chung, K. M. (1999). Effects of cooperative learning on mathematics performance for students with learning difficulties. Unpublished dissertation, The University of Hong Kong, Hong Kong. [Online] Available: http://hub.hku.hk/bitstream/10722/26562/1/FullText.pdf?accept=1.

Director, S. W., Doughty, P., Gray, P. J., Hopcroft, J. E., \& Silvera, I. F. (2006). Observations on undergraduate education in computer science, electrical engineering, and physics at select universities in Vietnam (A report presented to the Vietnam Education Foundation by the Site Visit Teams of the National Academies of the United States). Ha Noi: Vietnam Education Foundation. [Online] Available: http://www.home.vef.gov/download/Report_on_Undergrad_Educ_V.pdf (April 9, 2009).

Doymus, K., Karacop, A., \& Simsek, U. (2010). Effects of jigsaw and animation techniques on students' understanding of concepts and subjects in electrochemistry. Educational Technology Research and Development, 58(6), 671-691. http://dx.doi.org/10.1007/s11423-010-9157-2

Eva, C. E. W. (2003). The application of cooperative learning in a remedical classroom in Hong Kong - A case study. Unpublished dissetation, Hong Kong Baptist University, Hong Kong http://www.hkbu.edu.hk/ libimage/theses/abstracts/b18154621a.pdf.

Gillies, R. M. (2006). Teachers' and students' verbal behaviors during cooperative and small-group learning. British Journal of Educational Psychology, 76(2), 271-287. http://dx.doi.org/10.1348/000709905X52337

Harman, G., \& Nguyen, T. N. (2010). Reforming teaching and learning in Vietnam's higher education system. In G. Haaland, M. Hayden \& T. Nghi (Eds.), Reforming Higher Education in Vietnam: Challenges and Priorities (pp. 65-86). London: Springer. http://dx.doi.org/10.1007/978-90-481-3694-0_5

Hofstede, G., \& Hofstede, J. (2005). Cultures and organization-software of the minds (2nd ed.). New York: McGraw-Hill.

Hwang, N.-C. R., Lui, G., \& Tong, M. Y. J. W. (2005). An Empirical Test of Cooperative Learning in a Passive Learning Environment. Issues in Accounting Education, 20(2), 151-165. http://dx.doi.org/10.2308/iace.2005.20.2.151

Johnson, D. W., \& Johnson, R. (1981). Effects of cooperative and individualistic learning experiences on interethics interaction. Journal of Educational Psychology, 73(3), 454-459. http://dx.doi.org/10.1037/0022-0663.73.3.444 
Johnson, D. W., \& Johnson, R. (2005). New Developments in Social Interdependence Theory. Genetic, Social, \& General Psychology Monographs, 131(4), 285-358. http://dx.doi.org/10.3200/MONO.131.4.285-358

Johnson, D. W., \& Johnson, R. T. (1989). Cooperation and Competition: Theory and Practice. Edina, MN: International Book Company.

Johnson, D. W., \& Johnson, R. T. (1998). Cooperative learning and social interdependence theory. [Online] Available: http://www.co-operation.org/pages/SIT.html

Johnson, D. W., \& Johnson, R. T. (2008). Social Interdependence Theory and Cooperative Learning: The Teacher's Role. In R. M. Gillies, A. Ashman \& J. Terwel (Eds.), Teacher's Role in Implementing Cooperative Learning in the Classroom (pp. 9-37). New York, U.S.A: Springer. http://dx.doi.org/10.1007/978-0-387-70892-8_1

Johnson, D. W., \& Johnson, R. T. (2009). An Educational Psychology Success Story: Social Interdependence Theory and Cooperative Learning. Educational Researcher, 38(5), 365-379. http://dx.doi.org/10.3102/0013189X09339057

Johnson, D. W., Johnson, R. T., \& Holubec, E. (1994). The new circles of learning: Cooperation in the classroom and school $\left(3^{\text {rd }}\right.$ ed.). Alexandre Virginia: Association for Supervision and Curriculum Development.

Kagan, S., \& Kagan, M. (2009). Kagan Cooperative Learning (1st ed.). San Clemente, CA: Kagan Publishing.

Kilic, D. (2008). The Effects of the Jigsaw Technique on Learning the Concepts of the Principles and Methods of Teaching. World Applied Sciences Journal, 4(1), 109-114.

Kose, S., Sahin, A., Ergun, A., \& Gezer, K. (2010). The effects of cooperative learning experience on eighth grade students' achievement and attitude toward science. Education, 131(1), 169-180.

Lampe, J. R., Rooze, G. E., \& Tallent-Runnels, M. (1996). Effects of Cooperative Learning Among Hispanic Students in Elementary Social Studies. The Journal of Educational Research, 89(3), 187-191. http://dx.doi.org/10.1080/00220671.1996.9941324

Liang, T. (2002). Implementing Cooperative Learning in EFL Teaching: Process and Effects (Doctoral dissertation, National Taiwan Normal University). [Online] Available: http://www.asian-efl-journal.com/Thesis_Liang_Tsailing.pdf (July 17, 2009)

Luu, T. T. (2010). Infusing Cooperative Learning into an EFL Classroom. English Language Teaching, 3(2), 64-77. [Online] Available: http://www.ccsenet.org/journal/index.php/elt/article/view/6240/5012

McKeachie, W. (1999). Teaching Tips: Strategies, Research and Theory of College and University Teachers (10 ${ }^{\text {th }}$ ed.): Houghton Mifflin, Boston M.A, USA.

Messier, W. (2003). Traditional teaching strategies versus cooperative teaching strategies: Which can improve achievement scores in Chinese middle schools? Journal of Student-Centered Learning, 2(3), 231-238.

Ministry of Education and Training of Vietnam [MOET] (2009). Development Strategy from 2009 to year 2020 for the Cause of Industrialization and Modernization of Vietnam. Hanoi: Vietnamese Government.

Nguyen, P. M., Elliott, J. G., Terlouw, C., \& Pilot, A. (2009). Neocolonialism in education: Cooperative learning in an Asian context. Cooperative Education, 45(1), 109-130. http://dx.doi.org/10.1080/03050060802661428

Nguyen, P. M., Terlouw, C., Pilot, A., \& Elliott, J. G. (2009). Cooperative learning that features a culturally appropriate pedagogy. British Educational Research Journal, 35(1), 857-875.

Nhu-Le, T. (1999). A Case Study of Cooperative Learning in Inorganic Chemistry Tutorials at the Vietnam National University-Ho Chi Minh City (Master dissertation, University of Simon Fraser, Canada). [Online] Available: http://www.ir.lib.sfu.ca/bitstream/1892/8731/1/b19483041.pdf (March, 19, 2010)

O'Donnell, A. M. (1996). The effects of explicit incentives on scripted and unscripted cooperation. Journal of Educational Psychology, 88(1), 74-86. http://dx.doi.org/10.1037/0022-0663.88.1.74

O'Donnell, A. M. (2000). Interactive effects of prior knowledge and material format on cooperative teaching. Journal of Experimental Education, 68(2), 101-108. http://dx.doi.org/10.1080/00220970009598497

Park, C. C. (2002). Cross-cultural differences in learning style of secondary English learners. Bilingual Research Journal, 26(2), 443-459. http://dx.doi.org/10.1080/15235882.2002.10668720

Sachs, G. T., Candlin, C., Rose, K. R., \& Shum, S. (2003). Learner behavior and language acquisition project: Developing cooperative learning in the EFL/ESL secondary classroom. RELC Journal, 34(3), 338-369. 
http://dx.doi.org/10.1177/003368820303400305

Sahin, A. (2010). Effects of Jigsaw III technique on achievement in written expression. Asia Pacific Education Review, 12(3), 427-435. http://dx.doi.org/10.1007/s12564-010-9135-8

Sheridan, G. (2010). Preparing the Higher Education Sector Development Project - Developing New Model Universities (NMUs) in Vietnam. Ha Noi: Ministry of Education and Training.

Slavin, R. E. (1990). Cooperative learning: Theory, research, and practice. (2nd ed.). New Jersey: Prentice Hall.

Slavin, R. E. (2011). Instruction Based on Cooperative Learning. In R. E. Mayer \& P. A. Alexander (Eds.), Handbook of Research on Learning and Instruction (pp. 344-360). New York: Taylor \& Francis.

Sousa, D. A. (2006). How the brain learns (3rd ed.). Heatherton, Vic: Hawker Brownlow Education.

Souvignier, E., \& Kronenberger, J. (2007). Cooperative learning in third graders' jigsaw groups for mathematics and science with and without questioning training. British Journal of Educational Psychology, 77, 755-771. http://dx.doi.org/10.1348/000709906X173297

Tan, I. G. C., Sharan, S., \& Lee, C. K. E. (2007). Group Investigation Effects on Achievement, Motivation, and Perceptions of Students in Singapore. The Journal of Educational Research, 100(3), 142-154. http://dx.doi.org/10.3200/JOER.100.3.142-154

Tanel, Z., \& Erol, M. (2008). Effects of Cooperative Learning on Instructing Magnetism: Analysis of an Experimental Teaching Sequence. American Journal of Physics and Education, 2(2), 124-136.

Thanh-Pham, T., Gilles, R., \& Renshaw, P. (2008). Cooperative learning (CL) and academic achievement of Asian students: A true story. International Education Studies, 1(3), 82-88.

Thanh-Pham, T. (2011). An Investigation of Perceptions of Vietnamese Teachers and Students toward Cooperative Learning. International Education Studies, 4(1), 3-12.

Tran, V. D., \& Lewis, R. (2012a). Effects of Cooperative Learning on Students at An Giang University in Vietnam. International Education Studies, 5(1), 86-99. http://dx.doi.org/10.5539/ies.v5n1p86

Tran, V.D., \& Lewis, R. (2012b). The effects of Jigsaw Learning on Students' Attitudes in a Vietnamese Higher Education Classroom. International Journal of Higher Education, 1(2), 1-13. http://dx.doi.org/10.5430/ijhe.v1n2p9

Volet, S., \& Renshaw, P. (1996). Chinese students at an Australian university: Adaptability and continuity. In D. A. Watkins \& J. Biggs (Eds.), The Chinese Learner: Cultural, Psychological and Contextual Influences (pp. 205-220). Hong Kong: The Central Printing Press.

Webb, N. M. (2008). Learning in small groups. In T. L. Good (Ed.), 21 st Century education: A reference handbook (pp. 203-211). Los Angeles: Sage. http://dx.doi.org/10.4135/9781412964012.n22

Whicker, K. M., Bol, L., \& Nunerery, J. A. (1997). Cooperative learning in the Secondary Mathematics Classroom. The Journal of Educational Research, 91(1), 42-48. http://dx.doi.org/10.1080/00220679709597519

Wyk, M., M. (2010). The effects of Teams-Games-Tournaments on Achievement, Retention, and Attitudes of Economics Education Students. Journal of Social Sciences, 26(3), 183-193.

Yamarik, S. (2007). Does cooperative learning improve student learning outcomes? (Research in Economic Education)(Report). The Journal of Economic Education, 38(3), 259-277. http://dx.doi.org/10.3200/JECE.38.3.259-277

Zain, Z. M., Subramaniam, G., Rashid, A. A., \& Ghani, E. K. (2009). Teaching Students' Performance and Attitude. Canadian Social Science, 5(6), 92-102.

Zakaria, E., Chin, L. C., \& Daud, Y. (2010). The Effects of Cooperative Learning on Students' Mathematics Achievement and Attitude toward Mathematics. Journal of Social Sciences, 6(2), 272-275. http://dx.doi.org/10.3844/jssp.2010.272.275 